\title{
Infância e espacialização do bairro judeu nos romances Bom Retiro, de Eliezer Levin e A Guerra no Bom Fim, de Moacyr Scliar
}

Elcio Cornelsen

Universidade Federal de Minas Gerais

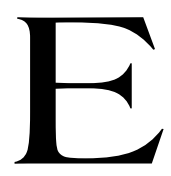

m estudos literários comparados, grosso modo, costuma-se estabelecer uma relação entre obras e autores, no intuito de se detectar a presença de aspectos comuns e distintos entre elas. Partindo da temática "Infância, Literatura e Outras Artes", optamos justamente por enfocar duas obras que, no nosso modo de ver, não só se ajustam a tal temática, como também possibilitam reflexões acerca de suas semelhanças e diferenças: mais precisamente, os romances Bom Retiro, de Eliezer Levin e A Guerra no Bom Fim, de Moacyr Scliar.

As semelhanças entre ambas as obras começam já pelo ano de publicação: 1972. Ambas têm um significado inaugural em comum, pois se trata do primeiro romance publicado tanto por Eliezer Levin quanto por Moacyr Scliar. E as semelhanças não param por aí: de origem judaica, Levin e Scliar retratam a infância nos bairros judeus do Bom Retiro, em São Paulo, e, respectivamente, do Bom Fim, em Porto Alegre. Seguindo os passos de autores como Scholem Aleichem (1859-1916) e Isaac Bashevis Singer (19041991), mestres da Literatura Iídiche que emigraram para os Estados Unidos da América, Levin e Scliar transportam para o espaço urbano do bairro judeu o modus vivendi das pequenas aldeias do Leste europeu, e este processo passa necessariamente pelo olhar das crianças, protagonistas de ambos os romances.

$\mathrm{Na}$ Literatura Iídiche, encontramos traços de representação do shtetl, palavra que designa a típica aldeia judaica do Leste europeu, como também 
reflexos do processo de imigração judaica rumo às Américas a partir do final do século XIX. ${ }^{1}$ Não é por acaso que a infância tenha se tornado um dos aspectos característicos em obras de autores que emigraram. Muitas vezes, a saída traumática de seu habitat e a nova realidade num mundo estranho, e mesmo o trânsito de uma cultura a outra, fizeram com que a geração de autores imigrantes investisse em estratégias de representação literária, nas quais haveria espaço tanto para a nostalgia e para o culto à tradição, quanto para o olhar da criança, que crescia em meio a dois mundos: o mundo familiar arraigado na tradição do shtetl, deixado para traz, e o mundo da rua, marcado no olhar infantil pelo desconhecido e, ao mesmo tempo, pela aventura. Deles, resulta uma tensão dialética entre Identidade e Alteridade, entre preservação e integração.

Como frisamos anteriormente, a transposição ficcional do espaço cultural judaico do Leste europeu para o espaço urbano brasileiro é mais uma das marcas comuns entre ambos os romances. Embora Moacyr Scliar e Eliezer Levin pertençam à primeira geração de filhos de imigrantes judeus oriundos do Leste europeu, os romances A Guerra no Bom Fim e Bom Retiro estão ancorados na tradição literária em lídiche e, portanto, fundamentamse em estratégias que lembram as obras dos mestres da geração de imigrantes. Podemos afirmar que ambos os autores investem ficcionalmente no processo de "shtetlização" de espaços urbanos brasileiros nos quais ocorreu um adensamento de imigrantes judeus nas décadas de 20, 30 e 40 do século XX, como é o caso do bairro porto-alegrense do Bom Fim e do bairro paulistano do Bom Retiro, de maneira que as obras assumem uma temática inegavelmente regionalista em miniatura. Tais espaços urbanos transformam-se em verdadeiros espaços da memória a partir do olhar infantil, o qual possibilita uma variedade de representações que estabelecem também relações com outras Artes.

Sem dúvida, um fator decisivo que levou a ambos os autores optarem pela representação do cotidiano nos bairros do Bom Fim e do Bom Retiro a partir do olhar infantil tem suas origens na biografia de cada autor: nascido em 23 de março de 1937 na cidade de Porto Alegre, Moacyr Scliar cresceu no Bom Fim, enquanto Eliezer Levin, também gaúcho, nascido em 22 de outubro de 1930 no interior do Rio Grande do Sul, mudou-se com sua família para São Paulo em 1935, vindo a residir no Bom Retiro durante sua infância.

\footnotetext{
${ }^{1}$ Cf. CORNELSEN, 2002, p. 321.
} 
Cabe salientar que os dois romances também se aproximam quanto ao período de tempo representado. No romance Bom Retiro, composto por 33 capítulos independentes entre si, ocorre uma delimitação temporal precisa, de 1938 a 1943: o narrador-protagonista adulto, tomando por base a memória de infância, inicia sua narrativa aos oito anos de idade e a encerra com a celebração de seu Bar-Mitzva - cerimônia do reconhecimento religioso da maioridade judaica -, ao completar treze anos. Por sua vez, no romance A Guerra no Bom Fim, composto por 30 capítulos, o eixo temporal transcorre de 1943 até o final dos anos 60, início dos anos 70, embora os relatos se tornem esparsos após 1945, de maneira que praticamente duas décadas e meia se reduzem às últimas catorze páginas do romance. Ligado ao eixo temporal, um acontecimento histórico tem influência direta na forma como seus protagonistas rememoram sua infância: a Segunda Guerra Mundial.

Em primeiro lugar, devemos considerar o legado literário í́diche como uma das fontes de inspiração para Scliar e Levin. Sem dúvida, um dos mestres da Literatura Iídiche cujas obras encontram ressonância nos romances Bom Retiro e A Guerra no Bom Fim é Scholem Aleichem, aliás, pseudônimo de Scholem Rabinóvitch (1859-1916), que significa "A Paz Seja Convosco". Originário de Pereieslav, uma cidade próxima de Kiev (atual Ucrânia), Scholem Aleichem emigrou em 1914 para os Estados Unidos da América, onde faleceu no ano de 1916. Jacó Guinsburg, um dos maiores estudiosos da Literatura Iídiche no Brasil, revela algumas peculiaridades das obras de Scholem Aleichem, entre elas, uma que certamente tornou-se referência para as futuras gerações de escritores em relação à representação dos espaços étnicos judeus pelo mundo afora: a presença de "crianças travessas e sonhadoras", como é o caso do romance Motl Peissi dem Khazns (Motl Peissi, Filho do Cantor, 1915), escrito nos Estados Unidos, apontado por Jacó Guinsburg como "uma epopéia chaplinesca da vida infantil em Kasrílevke e registro das vicissitudes da emigração e da aventura americana do judeu leste-europeu." ${ }^{2}$ Nessa obra, o protagonista Motl é construído no sentido de possibilitar a representação do processo de emigração da comunidade judaica da aldeia de Kasrílevke - uma cidadezinha fictícia, sempre presente na obra de Scholem Aleichem - para Nova Iorque a partir do olhar infantil. Podemos, portanto, estabelecer uma relação de continuidade da tradição literária iídiche nos romances Bom Retiro e A Guerra

${ }^{2}$ GUINSBURG, 1996, p. 96. 
no Bom Fim, na medida em que seus autores elegem crianças como protagonistas no intuito de representar os bairros étnicos judeus nas grandes cidades brasileiras, processo este que, ao mesmo tempo, os atrela à Série Literária Brasileira enquanto estratégia de representação da chamada "negociação cultural".

Nosso próximo passo nos conduz a uma reflexão sobre a "espacialização" ficcional dos bairros do Bom Retiro e do Bom Fim nas respectivas obras. Nelas, encontramos definições dos bairros étnicos judaicos que tendem à miniaturização do espaço ficcional a partir do olhar infantil. Logo no início do romance Bom Retiro, o narrador-protagonista justifica a mudança da família para o principal bairro judeu de São Paulo a partir do olhar dos pais, por que lá encontraram uma base comunitária bem estruturada, com escola judaica e sinagoga. ${ }^{3}$ Entretanto, seu olhar infantil revela um outro significado que estabelece um distanciamento da visão dos adultos:

Para nós, garotos, o mundo todo resumia-se no Bom Retiro. O que estivesse fora dele ficava tão distante quanto a lua. Não tínhamos queixas a fazer. Os problemas dos adultos não entendíamos e pouco nos afligiam. Contemplávamos a vida correr sem sobressaltos nem surpresas. ${ }^{4}$

A miniaturização do espaço ficcional, que traz consigo a atmosfera do antigo shtetl do Leste europeu, também se cristaliza logo no parágrafo de abertura do romance A Guerra no Bom Fim, conforme as palavras do narrador, projetadas a partir do olhar do protagonista Joel: "Consideremos o Bom Fim um país - um pequeno país, não um bairro em Porto Alegre". 5

Deste modo, as personagens infantis em ambos os romances exercem a função de mediadoras de espaços míticos. Embora mantenham ligações com as respectivas topografias, evocadas pela menção recorrente das principais ruas de cada bairro, são construídas de modo a "darem asas" à imaginação, a sonhar, a indagar e interpretar os problemas e questões dos adultos através do viés da fantasia e do elemento onírico, acompanhados do peculiar humor judaico.

Como exemplo de referencialidade desse procedimento ficcional elegemos o pintor judeu-russo Marc Chagall (Mark Zakharovich Shagal; 1887-

\footnotetext{
${ }^{3}$ Cf. LEVIN, 1987, p. 7.

${ }^{4}$ LEVIN, 1987, p. 121.

5 SCLIAR, 2001, p. 5.
} 
1985). Embora tenha vivido grande parte de sua vida na França, para onde emigrou em 1923, aos 36 anos de idade, Chagall também retratou com muita propriedade o mundo das aldeias judaicas do Leste europeu. A pequena cidade natal de Vitebsk (localizada na atual Bielorússia) está retratada em uma série de telas, nas quais o pintor dá vazão a lembranças de infância vividas no shtetl a partir da associação de mitos e sonhos em meio a um processo de criação surrealista. Suas numerosas obras representam cenas do cotidiano nos vilarejos judaicos da Rússia czarista. Sem dúvida, a presença da infância nas obras de Chagall como parte do processo memorialista do modus vivendi do shtetl repete o mesmo gesto que encontramos nas obras de autores da Literatura Iídiche, como já comentamos em relação a Scholem Aleichem, e está, portanto, intrinsecamente ligada ao processo de imigração.

O mundo surreal de Chagall, retratado muitas vezes através de traços e formas multicores que lembram desenhos infantis, também possui peculiaridades que atrelam a obra do pintor à tradição oral de narrativas do Leste europeu, sobretudo do shtetl com suas histórias povoadas de figuras fantásticas. Não é por acaso que várias de suas telas retratam personagens e objetos que pairam no ar, sobrevoando os céus das aldeias judaicas, como, por exemplo, a série de obras que retratam violinistas pairando acima dos telhados. Certa vez, o próprio Moacyr Scliar reconheceu a força das obras de Chagall e de Scholem Aleichem como autênticos retratos líricos do shtett:

[...] Não é de admirar que artistas como Chagall e escritores como Sholem Aleichem buscassem, na dura vida dos pequenos agricultores, artesãos e comerciantes, a inspiração para suas obras. Ao fazê-lo, captavam toda a emoção que caracterizava esse lugar, uma morada do coração. Pois a verdade é que os judeus amavam o shtetl. Era o seu lar, pobre e ameaçado, mas lar, em cujo telhado míticos violinistas tocavam as melodias melancólicas de um passado que se confundia com o presente. [...] (Scliar, 2000: 30)

Tal admiração por Scholem Aleichem e, principalmente, por Chagall transformou-se em estratégia intertextual no processo de construção do bairro mítico do Bom Fim. No romance de Scliar, aparecem quatro menções explícitas ao pintor russo. Na primeira delas, o narrador associa a personagem Nathan, irmão do protagonista Joel, com as personagens voadoras de Chagall:

[...] Ao crepúsculo, uma luz mágica, dourada, iluminava o Bom Fim. Nesse bairro, nesse pequeno país, a esta luz, Chagall teria visto os violinistas em lento vôo sobre os telhados; eram quatro; três, quem 
seriam? O quarto era Nathan, filho de Samuel e Shendl e irmão de Joel; Nathan, que teve uma hemoptise tocando 'A idishe Mame' e caiu morto sobre a estante. Esses violinistas nunca mais foram vistos; desapareceram durante a guerra (seres de pouca velocidade, seriam alvo fácil para os 'Stukas' e 'Messerschmitts'). [... ${ }^{6}$

Como podemos constatar, na passagem anterior o tema da guerra invade a imaginação, certamente pelas idas de Joel ao Cine Baltimore nas matinês de domingo, onde via filmes de guerra em que apareciam os aviões nazistas "Stukas" e "Messerschmitts". Mas decisivo mesmo para a cena é o lirismo chagalliano, onírico, um delírio de purezas e inocências, nostalgia de um "mundo perdido" que se torna elemento inspirador para a construção da personagem trágica Nathan, um violinista pairando acima dos telhados do Bom Fim.

No romance Bom Retiro, o tema de figuras fantásticas que voam também está presente. Num deles, claramente marcado pela tradição da narrativa oral do shtetl, fonte em que Chagall certamente bebeu, um amigo do narrador-protagonista conta-lhe sobre uma história que ouviu de sua mãe, dos tempos em que ainda residia na Polônia:

- Você julga que voar seja coisa só dos pássaros? - comentou Moischele e, sem esperar resposta, prosseguiu: - Pois eu também pensava assim, até que minha mãe me contou um fato curioso. Lá na sua terra, na Polônia, certas camponesas conseguem elevar-se a grandes alturas. De que modo? Muito simples, elas começam, feito um pião, a girar, a girar $\mathrm{e}$, quando atingem grande velocidade, $\mathrm{o}$ ar que enche suas saias as faz saltar. E saltam mais alto do que o teto de uma casa. Diante de minha perplexidade, Moischele arrematou:

- O segredo está na quantidade de saias, você me entende? É um segredo que elas não contam a ninguém. ${ }^{7}$

Tal história desperta a imaginação das crianças que, logo após, saem pelo bairro, caçando borboletas. Não tarda, e a fantasia realmente ganha "asas" gigantes, nas palavras de Moischele: "- Se for do tipo que penso, podem, com o tempo, ir crescendo, crescendo, até alcançar o tamanho dum avião. Imagine - continuou entusiasmado -, depois, quando nos der na veneta, é só montar e sair sobrevoando a cidade. Já pensou?” 8

\footnotetext{
${ }^{6}$ SCLIAR, 2001, p.7.

7 LEVIN, 1987, p.30.

${ }^{8}$ LEVIN, 1987, p.31.
} 
Mesmo não acreditando em nada do que Moischele disse, o narradorprotagonista ficou fascinado com a idéia, que, mais tarde, acaba encontrando espaço em seus sonhos: "Naquela noite, em minha cama, sonhei com a fenomenal borboleta. Eu voava montado nela, e suas enormes asas projetavam uma vasta sombra sobre as ruas do Bom Retiro".?

Por sua vez, Moacyr Scliar se vale também da tradição literária para compor as figuras aladas que povoam o Bom Fim da fantasia de Joel. Certa vez é o inseto da novela A Metamorfose, de Franz Kafka (1883-1924), que serve de inspiração para a composição de uma cena em que Marcos, um amiguinho de Joel, ao suicidar-se tomando veneno para matar barata, se transforma em um ser metamorfoseado a la Gregor Samsa: ${ }^{10}$ "[...] Uma espécie de secura apertou-lhe a garganta, desceu-lhe pelos braços e pernas que ficaram escuros e secos como patas de barata. E barata ele virou, uma barata grande que voava sobre o Bom Fim e olhava, divertida, o velório na rua Felipe Camarão". ${ }^{11}$

Entretanto, não é Kafka, mas sim Chagall que recebe maior espaço no romance. Duas das referências ao pintor russo estão ligadas à representação de animais que mais parecem seres híbridos, com atitudes humanas, mas também pairando no céu, outra marca do mundo do shtetl, que, como observa Gilda Salem Szklo, "reavivam a memória cultural e folclórica do judaísmo". ${ }^{12}$ Neste contexto, o narrador aponta para Chagall como o próprio artista que teria retratado os animais:

[...] A carrocinha puxada pelo bode 'Leibl', que Chagall pintou sentado sobre uma nuvem mirando a vila com olhar vazio. ${ }^{13}$

e

Chagall retrata a gata 'Lisl', com rosto quase humano, sentada sobre uma nuvem no céu. Observando-se bem, vê-se que ela não tem rabo. ${ }^{14}$

\footnotetext{
${ }^{9}$ LEVIN, 1987, p.31.

${ }^{10}$ Cf. CORNELSEN \& CURY, 2004, p.161.

${ }^{11}$ SCLIAR, 2001, p.15.

${ }^{12}$ SZKLO, 1990, p.74.

${ }^{13}$ SCLIAR, 2001, p.57.

${ }^{14}$ SCLIAR, 2001, p.69.
} 
Seres híbridos e animais também aparecem no mundo da fantasia do romance Bom Retiro, de Eliezer Levin. Um deles, que se destaca, resulta da animalização de Hitler no contexto da guerra. Ouvindo os adultos se referirem ao ditador como "cachorro", o narrador-protagonista, sem saber ao certo de quem se tratava, ativou mais uma vez sua imaginação. No começo, achava que, realmente, se tratava de um cachorro, embora não compreendesse "como, de que jeito, um cachorro podia fazer tanto mal". ${ }^{15}$ Um dia, indagando Moischele, o filho do sapateiro, um de seus amiguinhos do bairro, ouviu dele a confirmação de que Hitler era, de fato, um cachorro. E Moischele ainda ampliou a imagem fantástica que faziam do ditador: "- Está aí, só pode ser um cachorro raivoso, com asas, voando de um continente a outro" .

Portanto, a fantasia reinante e o gesto infantil de se tomarem expressões ao pé da letra fazem com que Hitler seja imaginado como se fosse um ser híbrido ameaçador. Em outra oportunidade, são as estátuas dos leões que ladeavam a Arca Sagrada na Sinagoga, que parecem seres ameaçadores e, ao mesmo tempo, fascinantes aos olhos do narradorprotagonista: "De tudo à minha volta, o que mais me chamava a atenção era o grande armário. Nas cortinas vermelhas de veludo, dois terríveis leões, de pé, sustentavam as pedras do Decálogo de Moisés. [...] Os terríveis leões fascinavam-me". ${ }^{16}$

Poderíamos, ainda, enumerar uma longa série de exemplos que nos permitem ilustrar o papel central que a infância assume tanto em termos temáticos, como também constitutivos no que toca a questão do foco narrativo. Sem dúvida, o olhar nostálgico do imigrante, que encontramos em obras da Literatura Iídiche e na Pintura de Marc Chagall, acompanha também o olhar das personagens infantis de obras da Literatura de Imigração judaica no Brasil, como Bom Retiro e A Guerra no Bom Fim. Sendo assim, fundamentadas em uma longa tradição oral dos contadores de histórias do Leste europeu, que tinham nas aldeias judaicas seus espaços por excelência, tais obras contribuem de maneira significativa para a transposição memorialista para os trópicos de um mundo que não mais existe, inserindoo num novo processo de negociação cultural.

\footnotetext{
${ }^{15}$ LEVIN, 1987, p. 25.

${ }^{16}$ LEVIN, 1987, p. 20-21.
} 


\section{Referências Bibliográficas}

CORNELSEN, Elcio Loureiro; CURY, Maria Zilda Ferreira. Espaço étnico e traduções culturais em Moacyr Scliar e Eliezer Levin. In: ZILBERMAN, Regina; BERND, Zilá (Org.). O Viajante Transcultural. Leituras da obra de Moacyr Scliar. Porto Alegre: EDPUCRS, 2004. p.155-177.

CORNELSEN, Elcio Loureiro. O shtetl e seus sapateiros. In: SCARPELLI, Marli Fantini; DUARTE, Eduardo de Assis (Org.). Poéticas da Diversidade. Belo Horizonte: Ed. UFMG, 2002. p.318-342.

GUINSBURG, Jacó. Aventuras de uma lingua errante. Ensaios de língua e literatura ídiche. São Paulo: Perspectiva, 1996.

LEVIN, Eliezer. Bom Retiro. 2. ed. São Paulo: Perspectiva, 1987.

SCLIAR, Moacyr. A Guerra no Bom Fim. 8. ed. Porto Alegre: L\&PM, 2001.

SCLIAR, Moacyr. Memórias Judaicas. In: SCLIAR, Moacyr; SOUZA. Márcio. Entre Moisés e Macunaíma. Os judeus que descobriram o Brasil. Rio de Janeiro: Garamond, 2000. p.23-79.

SZKLO, Gilda Salem. O Bom Fim do Shtetl: Moacyr Scliar. São Paulo: Perspectiva, 1990. 


\section{Resumo}

Os romances Bom Retiro, de Eliezer Levin e A Guerra no Bom Fim, de Moacyr Scliar, ambos publicados em 1972, retratam a infância nos bairros judeus do Bom Retiro, em São Paulo, e do Bom Fim, em Porto Alegre, respectivamente. Seguindo os passos da tradição literária de autores como Scholem Aleichem, um dos mestres da Literatura Íidiche, Levin e Scliar transportam para o bairro judeu o modus vivendi das aldeias do Leste Europeu, e este processo passa necessariamente pelo olhar das crianças, protagonistas de ambos os romances. Outro aspecto que aproxima os referidos romances é o fato de que, neles, constata-se a relação entre a Literatura e outras Artes: no caso de Levin, o protagonista "amplia" seu universo através das matinês no cinema e das histórias em quadrinhos; no livro de Scliar, o protagonista transfere para o universo do Bom Fim desde imagens chagallianas até super-heróis.

\section{Resumen}

Las novelas Bom Retiro, de Eliezer Levin y A Guerra no Bom Fim, de Moacyr Scliar, ambas publicadas en el año 1972, retratan la infancia en los barrios judíos de Bom Retiro, en São Paulo, e de Bom Fim, en Porto Alegre, respectivamente. Siguiendo los pasos de la tradición literaria de autores como Scholem Aleichem, uno de los maestros de la Literatura Ídish, Levin y Scliar transportan para el barrio judío el modus vivendi de las aldeas de Europa del Este, y este proceso pasa necesariamente por la mirada de los niños, protagonistas de las dos novelas. Otro aspecto que acerca las referidas novelas es el hecho de que, en ellas, se observa la relación entre la Literatura y las otras Artes: en el caso de Levin, el protagonista "amplía" su universo a través de la matinée en el cine e de las historietas; en el libro de Scliar, el protagonista transfiere para el universo de Bom Fim desde imágenes chagallianas hasta superhéroes. 